\title{
Why don't the French do think tanks?: France faces up to the Anglo-Saxon superpowers, 1918-1921
}

\author{
ANDREW WILLIAMS*
}

\begin{abstract}
This article asks the question: 'Why have the French not developed "think tanks"?' by looking at the period when such institutions were being set up in The UK and the United States, during the preparation for the Paris Peace Conference and its aftermath. It is suggested that the reasons were a mixture of French bureaucratic and intellectual disposition but also in a growing revulsion in Paris at what was seen as duplicity and conspiracy by its Allies to ignore the legitimate concerns and needs of the French people. The central source material used is the papers of the 'Commission Bourgeois' whose deliberations are often rather air brushed out of academic literature on the period and work done within the French Foreign Ministry.
\end{abstract}

It is a remarkable feature of the international system of the twentieth century that the very concept of the 'Think Tank' has tended to be seen as having been invented and developed largely in Washington and London with little or no input from anyone or anywhere else. Hence the Washington 'Beltway' has its corresponding London 'West End' and, as many have pointed out, they have tended to talk to each other a great deal over the last hundred years or so. ${ }^{1}$ The explanations for the Anglo-Saxon nature of the phenomenon have usually been looked at by examining their Holy Places, from where it must be said they have often heaped derision on French attempts to influence the West and the Rest. This article proposes to look through the other end of the telescope, the view from Paris, as well as asking what gave the 'Anglo-Saxons' their often unwarranted sense of arrogance towards the French. It will show that the original optimism in Paris in 1918 for a new world after the war that would solve France's problems and lead to a really safe international system based on law was to be dashed on the mutual incomprehension of the Anglo-Saxon and French powers.

* A first version of this article was presented in a panel at the International Studies association in Chicago, February 2007. I would like to thank my fellow panel members for their comments, and in particular Inderjeet Parmar and Chris Hill. I would also like to thank several anonymous referees from the Review, one of whom was particularly helpful in clearing up my occasional errors and confusions, such as over the titles of personnel in the French Foreign Ministry.

1 See, for example, Diane Stone et al., 'Symposium on Think Tank Transnationalisation', Global Society, 14:2 (April 2000), pp. 149-236; Inderjeet Parmar, Think Tanks and Power in Foreign Policy (London, Palgrave, 2004); Inderjeet Parmar, 'Anglo-American Elites in the Interwar Years: Idealism and Power in the Intellectual Roots of Chatham, House and the Council for Foreign Relations', International Relations, 16:1 (April 2002), pp. 53-76, and D. Stone, Think Tanks across Nations (Manchester University Press, 1998). 
It could be argued that as a result France was isolated from the main avenues of liberal discourse that helped formulate late twentieth-century patterns of world order. France was correspondingly easy to defeat in 1940 while the American and British elites developed a working policy of rethinking the entire international system in their own image, one that still operates today.

This thesis will be developed by a consideration of an often neglected part of the pre-history of Think Tanks, by looking at French attempts to set up what could well have evolved into one of their own during the First World War - the 'Commission interministérielle d'études de la Société des Nations' (hereafter the 'Commission Bourgeois'), named after its Chairman Senator Léon Bourgeois. ${ }^{2} \mathrm{He}$ had spent much of the war until 1917 cataloguing in some detail German atrocities in areas of France they occupied after 1914 and harboured a deep and understandable resentment, not to say hatred, of what Germans had done to his Patrie. ${ }^{3}$ He became the main French inspiration for a League, and dedicated the rest of his life until 1925 to help it come about. His Commission, which first met on 28 September 1917 and completed its work in the Summer of 1918, planned the French attitude to the coming Peace Conference before the war ended in much the same way as the 'Inquiry' did in The United States and the Foreign Office did in London, a process which resulted in the famous British 'Blue Books' used in Paris in 1919.4

The article will also look into French thinking about United States' and British ambitions after the war, briefly touching on a French examination of articles in the Round Table, ${ }^{5}$ as well as the wider deliberations of the 'Inquiry'. ${ }^{6}$ In their preparations for the Conference the French Foreign Ministry (always called the 'Quai d'Orsay' after its magnificent position on the Seine opposite the Place de la Concorde) investigated these British and American efforts and give some further clues as to why they took the positions they did.

\section{Think Tanks, classes and elites in Britain, France and America}

As has been pointed out, the main story to be told about Think Tanks (and other forms of group foreign policy deliberation) is that their main wellspring is to be found

${ }^{2}$ Some relevant scholarship on the Commission in French includes: S. Blair, 'Les origines en France de la SDN: La Commission interministérielle d'études pour la Société des Nations, Relations Internationales, 75 (1993), pp. 277-92; and Marc Sorlot, Léon Bourgeois; un moraliste en politique (Berne: Peter Lang, 1995). In English the best book to address these issues is David Stevenson, French War Aims against Germany, 1914-1919 (Oxford University Press, 1982).

${ }^{3}$ Ministry of Foreign Affairs Archives, Paris, Leon Bourgeois Papers, various volumes during the period 1914-18, PA-AP 029, P16884.

${ }^{4}$ For an excellent account of British official planning for the Peace Conference see Erik Goldstein, Winning the Peace: British Diplomatic Strategy, Peace Planning and the Paris Peace Conference, 1916-1920 (Oxford: Clarendon Press, 1991). The best single book on the Conference is now: Margaret Macmillan, Peacemakers: The Paris Conference of 1919 and Its Attempt to End War (London: John Murray, 2001), See also Zara Steiner, The Lights that Failed: International History, 1919-1933 (Oxford University Press, 2005), and my Failed Imagination: American New World Orders from Wilson to Bush, 2nd edn. (Manchester University Press, 2007), chs 1 and 2.

5 Round Table was (and is) an informal but (then, not now) very influential British body, a proto-Think Tank founded in 1910, one that had a large elite membership on both sides of the Atlantic and a journal with a then huge readership.

${ }^{6}$ For the best overview of Round Table's influence from 1910 until the 1950s see: A. May, The Round Table, 1910-66, Ph.D. dissertation, Oxford, 1995. 
essentially in the nature and organisation of middle-class elites, especially AngloSaxon ones. Many 'critical' theorists generally see the evident Anglo-American intellectual cooperation in the field of IR since about 1918 and its ensuing policy choices as evidence of the emergence of a 'transnational', or even an 'AngloAmerican class', one based on shared capitalist aspirations that has, in the words of Inderjeet Parmar, 'develop[ed] international networks - social, economic, ideological, and begins the process of creating a transnational capitalist class, over and above the nation-state'. Writers in this school include Kees van der Pijl, Robert Cox, Stephen Gill and Craig Murphy. They also see in Think Tanks yet more evidence of a drive for American hegemony. ${ }^{7}$ Gramscian Marxists like Gill and Cox would also point to the links between this economic and political networking to the emergence of an 'intellectual' hegemony. ${ }^{8}$

Of course they are not wrong to see evidence of such links, though it is arguable that they overstate their case on the existence of a 'class'. A class has to have rather stronger links than I at least can see evidence for. For example, it is now arguable that American IR as an academic discipline is dominated by formal theory, not the case in Britain, where philosophical and historical approaches to IR are more in vogue. It may be that this even demonstrates that we are seeing a slow realignment of the elites as the British finally look more to Europe (and France) than the United States for inspiration. However, the non-involvement (on the whole) of the French elite in the elaboration of world order thinking since 1918 could nonetheless be said to act as a useful piece of supporting evidence for the critical theorists. The French elite is far more wedded to statist and patrimonial forms of government and to inveighing against Anglo-Saxon dominance in France itself, Europe and the Third World than in collaborating with American and British elites since 1918. This came through very strongly in and after the Second World War, as it also did in the First, and has continued since. ${ }^{9}$

The Commission Bourgeois was in any case well aware of its lack of intellectual hegemony at the forthcoming Paris Peace Conference. Long before 1918 it was Woodrow Wilson who had managed to dominate the international moral debate on war aims, even though it was the British who had stolen a march on the detailed implications of this. As I have discussed elsewhere, there were a number of key players in the slow elaboration of a vision of a postwar world. In Britain these included the populist Union of Democratic Control, run by the key 'Lib-Lab' political figure E. D. Morel, ${ }^{10}$ and the later League of Nations Union where key liberal thinkers like Gilbert Murray and Robert Cecil played a substantial guiding role. Many of these figures saw their initial organisation in the 'Bryce Group' of late 1914, given its name by its initial mentor James Bryce, who had been an Ambassador to Washington under Presidents Theodore Roosevelt and William Howard Taft and

7 K. van der Pijl, Transnational Classes and International Relations (London, Routledge, 1998); Inderjeet Parmar 'CFR - RIIA Interconnections: A Nascent Transnational Ruling Class, Liberal Atlantic Community, or Anglo-American Establishment?'

${ }^{8}$ For a full view of S. Gill's work see his American Hegemony and the Trilateral Commission (Cambridge University Press, 1990, and: Gramsci, Historical Materialism and International Relations (Cambridge University Press, 1993).

9 See, for example, my: 'France and the New World Order, 1940-1947', in Modern and Contemporary France, 8:2 (May 2000), pp. 191-202.

${ }^{10}$ His most influential book actually appeared before the First World War: E. D. Morel, Ten Years of Secret Diplomacy: An Unheeded Warning (London: National Labour Press, 1912, 1915), pp. xvii-xix. 
who can be seen as a key physical and intellectual link to thinkers and activists around Wilson. These British players, with the possible exception of Morel, were also eminently 'Establishment' figures and formed the natural focus for disillusion and thinking about what the 'next step' should be as dissatisfaction with the policies off Herbert Asquith's Coalition Government grew after 1916. This was a kind of emerging 'counter elite' that was to have a huge influence on IR in theory and practice in the inter-war period, often through Think Tanks like Chatham House, the Council on Foreign Relations (CFR) and Carnegie, as well as in 'informal' bodies like Round Table in cementing Anglo-American elite cooperation. ${ }^{11}$

Wilson, and various internationalists of the progressive and conservative persuasions, ${ }^{12}$ and the emerging counter-elite among his British Allies rapidly came to think of themselves as the torch-bearers of a new insistence that this should be the "War to End All Wars' and impatience grew rapidly with what was seen as the other partner in the Coalition to defeat Germany. The French were seen, and not for the last time, as standing in the way of 'progress', wedded to out-of-date ideas and practices, clinging to an outdated 'gloire' and, worse still, clinging to ideas that many in Washington and London felt had actually caused the war in the first place. Partly this was an inter-generational conflict, with the French leadership having spent far more of its life in the nineteenth than the twentieth century (Georges Clemenceau was in his late 70s, Bourgeois had been a delegate to the Hague Conference of 1899), with their key points of reference being the Franco-Prussian war, the Commune of 1871 and their political behaviour developed within the rickety framework of the Third Republic. This had given them all a deep suspicion of social experiments and anything that went beyond the 'normal' in international relations.

The British and American experts on the Inquiry and Blue Book teams on the other had were largely young, liberal and enthusiastic for change. Partly the cleavage also reflected the different experiences of the British, Americans and French in the war. For all it had been costly, but for the French it had been devastating, with a far higher proportion of its young men killed than was the case even for the British (a fact that French historians still moan about). ${ }^{13}$ The new British and American thinkers and policymakers were also very hopeful that elite cooperation could generate new ideas and practices. Early deliberations of the Carnegie Foundation for International Peace (founded 1910), and its 1913 Report on the Balkan Wars, set a new benchmark for international investigation that cut through the official propaganda that many of them saw as a feature of the closed diplomacy that had helped create the war. ${ }^{14}$ After the signature of the Treaty of Versailles, Foreign Office

11 'Before the Special Relationship: The Council on Foreign Relations, The Carnegie Foundation and the Rumour of a Anglo-American War', Journal of Transatlantic Studies, 1:2 (Autumn 2003), pp. 233-51.

12 See Williams, Failed Imagination, pp 32-5.

13 See, for example, Pierre Miquel, Le Chemin des Dames: Enqûete sur la plus effroyable hécatombe de la Grande Guerre (Paris: Librarie Académique, Perrin, 1997).

14 Report of the International Commission To Inquire into the Causes and Conduct of the Balkan Wars (1913), republished by the Carnegie Endowment as: The Other Balkan Wars: A 1913 Carnegie Endowment Inquiry in Retrospect with a New Introduction and Reflections on the Present Conflict by George F. Kennan (Washington, DC: Carnegie Endowment for International Peace, 1993). Ironically there were French contributors to this. Also ironically, the 'official' report that most irritated the future members of the Council on Foreign Relations and Chatham House was none other than James Bryce with his report on the Belgian 'atrocities' of 1914, later shown to be largely, though not entirely, fabricated or exaggerated to rouse British bloodlust again Germany. 
veterans like E. H Carr, Alfred Zimmern and Philip Noel-Baker returned to civilian life and were all to become professors of the new discipline of IR. In the United States many of the policymakers in the Inquiry or the official delegation now returned to their university posts or helped set up Think Tanks, like the Council on Foreign Relations, whose main luminary Hamilton Fish Armstrong was its young Secretary and who had a huge impact on American thinking on IR over the next thirty years.

So scattered though the deliberations of the Commission Bourgeois are references to the dominance of liberal thinking, or statements and procedures 'faithful to the anglo-saxon tradition' as the French Ambassador in Washington, Jean Adrien Jusserand, put it. ${ }^{15}$ The French had a very serious reason to want to counter this. They had been invaded twice, and had lost millions of young men in action, as a visit to any part of France even today will testify. Much of what passes for romantic abandoned countryside is literally that, abandoned when the majority of men of working age were wiped out, their fiancées waiting in vain for boyfriends annihilated in the German onslaught in 1914, or at Verdun (1916) and the Chemin des Dames (1917), names that have little notoriety in a Britain generally rather intelligently aware of the First World War, and even less in the United States today. France's response was as Anthony Adamthwaite points out, a 'bid for power in Europe', one which was as frenetic as any forgotten episode can ever have been, and even by its supporters 'ended' by 1924 and the imposition of an American-led financial settlement (The Dawes Plan) in 1924. ${ }^{16}$ This was often interpreted in London and Washington as unduly aggressive, but Stephen Shuker is surely right to emphasise that ' $[t]$ he mood in France in the years after Versailles, often misinterpreted as bellicose in a world yearning for restoration of an effective peace, actually was nervous and defensive'. ${ }^{17}$

The thinking that took place in France between 1914 and 1919 was thus a vital part of France's serious attempt to make sure that its voice was heard at the top table of postwar order making. On the other hand we do not have to look far in British and American archives of the period and books on the results of the Paris Peace Conference to find carping remarks about the French and especially their 'bellicosity'. Even those who profess to love the country have always found they can raise a salacious giggle; Anthony Adamthwaite asked rhetorically: 'Why study French policy? Of course the sub-plot of scandal and sleaze has a racy readability, half Feydeau farce, half Chevalier's Clochemerle' and this was especially the case before 1940, for 'Publishers know they can sell any amount of books about France', wrote Nancy Mitford, 'in fact, France, like Love, is a certain winner on a title page.' 18 The French were, somehow, not quite serieux.

The criticisms were not all without an edge of admiration. Harold Nicholson, who served as part of the British delegation to Paris and wrote one of the best eyewitness accounts, was well aware of the shortcomings of Wilson's vision:

15 French Ambassador to Washington Jusserand, MAE 13/218, Ministry of Foreign Affairs, Paris, 1921.

16 Anthony Adamthwaite, Grandeur and Misery: France's Bid for Power in Europe, 1914-1940 (London: Arnold, 1995); Stephen Shuker, The End of French Predominance in Europe: The Financial Crisis of 1924 and the Adoption of the Dawes Plan (Chapel Hill, NC: University of North Carolina Press, 1976).

17 Shuker, The End of French Predominance in Europe, p. 5.

18 Adamthwaite, Grandeur and Misery, p. vii. The Nancy Mitford quote is from Don't Tell Alfred (London, 1980), p. 63. 
The Anglo-Saxon [sic] is gifted with a limitless capacity for excluding his own practical requirements from the application of the idealistic theories which he seeks to impose on others. Not so the Latin. The logical precision of the French and to a less extent the Italian, genius does not permit such obscurantism. The Anglo-Saxon is apt to accuse the Latin of 'cynicism' because he hesitates to adhere to a religion which he would not be prepared to apply to his own conduct as opposed to the conduct of others. The Latin accuses the Anglo-Saxon of 'cant' because he desires to force upon others a standard of behaviour which he would refuse to adopt himself. The contract between the two is not, in fact, one between cynicism and hypocricy, it is between two different habits of mind. The Anglo-Saxon is apt to feel before he thinks, the Latin is apt to think before he feels. It was this divergence of habit, this gap between reason and emotion, which induced the Latins to examine the Revelation of Woodrow Wilson in a manner more scientific, and therefore more critical, than we did ourselves. From this examination he reached certain deductions which destroyed their faith. ${ }^{19}$

Adamthwaite sums it up as 'preoccupation with logic and verbalism ... [t]he system inculcated a belief that a problem dealt with oratorically was a problem solved', a judgement supported by a reading of the Commission's papers. This, Adamthwaite underlines, 'did not go down well with British leaders who prized spontaneity, brevity and wit'. ${ }^{20}$ What it might be more accurate to say is that the French administrative style has been (and still is) one where a discursive, often complex and intellectual approach is more prized than (as the French would see it) a 'journalistic' summary of complex issues. At the same time as the French have been wrong-footed repeatedly by the Anglo-Saxons in the subject of IR, they have also inspired some of the more interesting 'critical' thinking about the subject, even if that has rarely been for its Anglo-Saxon readers one helped by an ability to read in the original French. So paradoxically at the same time as France has seen a century of decline in its political influence it has also been one of the 'siècle des intellectuels' in the words of Michel Winock. ${ }^{21}$

\section{The preparation for Versailles and the Commission Bourgeois}

The Commission and the Quai d'Orsay embarked on separate but linked investigations of both Anglo-Saxon hopes from the Conference and how the French should prepare themselves for it. It is therefore informative to show how the deliberations of the Commission and the Quai d'Orsay articulated their work and how this can be said to differ from their Anglo-Saxon counterparts. It was no less, and arguably a lot more, straightforward, as a counterpoise to the above denunciations of verbosity, in its approach than might be said of the Inquiry or the Blue Book team, though it was more 'ideas based', unlike the Anglo-Saxons who tended to eschew over-theorising in favour of area studies and suchlike. The calibre of the three teams was no doubt roughly equal. How do you compare the intellects of a Clemenceau, a Raymond Poincaré (his Prime Minister and successor as Président de la République), an André Tardieu, or a Jules Cambon, Sécretaire Générale (Administrative Head) of the Quai d'Orsay in 1919, with Herbert Hoover or Isaiah Bowman of the American delegation

\footnotetext{
19 Harold Nicolson, Peacemaking 1919 (London: Constable, 1933), pp. 193-4.

20 Adamthwaite, Grandeur and Misery, p. 9.

21 Michel Winock, Le Siècle des Intellectuels (Paris: Editions du Seuil, 1999).
} 
or Lord Robert Cecil, E. H. Carr or Arnold Toynbee of the British? In important ways neither were their brief and the questions they asked so different. What was arguably different was the point from which they started and their hopes for the future. Whereas the Anglo-Saxons wanted to 'move on' the French wanted to consolidate, as will be seen below.

What then were the French elite's 'deductions'?

\section{Why had the war been fought and what was to come next?}

The Commission's main concern was firstly to be sure why the war had to be fought and, secondly, what it had to lead to. In 1917 there was some real doubt as to whether France would not be defeated as its armies had been annihilated in the last great French offensive of the war on the Aisne, an offensive which led to mutinies, summary executions and an end to all pretensions of a 'break through', which had to be left to the Americans and British in August 1918. A very early session of the Commission had proposed the setting up of a Société des Nations (SDN, League of Nations) that would both be an extension of that had happened in the pre-war period, and especially at the Hague Conferences of 1899 and 1907. It was to be a multi-lateralisation of the principles of law established at these great disarmament conferences to which the French looked for inspiration. It was assumed that the main war aim was to 'establish Humanity under the rule of law'.22 Partly this was due to the precedent career of the main members of the Commission. Bourgeois had himself been at The Hague and saw the SDN as a multilateralisation of the bilateral arbitration treaties of the pre-1914 era, not as a new experiment in 'open diplomacy' as envisaged by Morel and Wilson. ${ }^{23}$

Senator Gabriel Hanotaux called the Hague meetings 'les premiers battements du coeur de l'humanité'. This required, in the words of Alexandre Ribot in 1916, a peace 'basée sur le droit international et garantie par des sanctions contre laquel aucun pays ne pourra se dresser' (his italics), a theme to which the Commission returned several times. ${ }^{24}$ But this had to be a Hague 'with power', not some sort of glorified 'Union des Télégraphes'. For another theme that comes through loud and clear is that the peace must not prove to be a truce, a claim most famously summed up later by Marshall Foch of the Treaty as announcing a 'Twenty Year Truce'. This view was voiced as early as 21 November 1917 in the 4th meeting of the Commission in a report by a Quai d'Orsay's legal advisor ('juriconsulte-adjoint') Henri Fromageot that 'the peace must be a real peace and not a dangerous truce'. This led to the question as to whether the 'pacte général d'association' should precede or follow the end of hostilities and how could it have teeth while not affecting the sovereignty of states. ${ }^{25}$ These were all questions that preoccupied the American Senate and have dogged international organisation ever since.

\footnotetext{
22 'Etablir l'humanité dans le regle du droit', Commission Bourgeois, 4ème séance, 19 December 1917, Ministere des Affaires Etrangeres archives (henceforth MAE), SDN 1.

23 'Open Covenants openly arrived at': Point 1 of the 14 Points of January 1918.

24 MAE, SDN 1 (Commission de la SDN, henceforth Commission Bourgeois), Séance d'ouverture, 21 November 1917, Ministry of Foreign Affairs Archives, Quai d'Orsay, Paris.

25 Commission Bourgeois, 4th meeting of 19 December 1917.
} 
But in spite of these vague feelings of disquiet, there was also reflected a generalised feeling that the unity of the Allies during the war was destined to be an unstoppable force in the coming peace. Perhaps the best illustration of this was an extraordinary document considered in June 1918 by the Commission: 'L'Union des Alliés'. After a long preamble enumerating the numerous areas where the war had forced economic, military and other areas of deep cooperation the riposte to the last German offensive of the war had 'placed the keystone for an Interallied Union' and this had led to the 'greatest victory since the Battle of the Marne' [in 1914]. What was now not possible? What the war had proved was that 'no state can now live in isolation. The United States had understood that their existence was linked to the free peoples of Europe. The great modern nations must belong to great mutually guaranteeing syndicates [syndicates] to safeguard their territory and their liberty.' What was now needed was to consolidate this into global institutions in a 'pacte général d'association' which would 'give the Allies an incomparable force to pursue the war and an irresistible weight in the peace that would end it'. ${ }^{26}$

There was a great deal of what would later be called 'functionalist' thinking in the conversations within and the documents considered by the Commission - the more you duplicate contacts the more there will be and the more this will overspill from 'low' into 'high' politics. The French word 'engrenage', later used by David Mitrany in the 1940s for his celebrated ideas on a 'Working Peace System' might have seen its origins in such thinking, though to show that would require more scholarship than we have space for here. ${ }^{27}$

\section{What could be expected of the Treaty?}

The Quai d'Orsay's reading of what the Americans wanted in late 1918 when Wilson arrived in Europe was based on an analysis of the 'Inquiry', which, as it turned out, was not helpful as Wilson all but ignored it. ${ }^{28}$ A first report by Emmanuel de la Martonne of October 1918 was by a man who had led a 'Comité d'Etudes' close to the Inquiry. He knew and liked most of the membership of the Inquiry, most of whom were Ivy League academics of his acquaintance. In his report in a telling remark he pointed out that these members of the Inquiry all liked France but knew England better. Even if they were not so pacifist or 'philogermaniques' as might have been the case, 'suspect influences are nonetheless to be feared'. The good news was that Wilson and Colonel House had set it up and controlled it tightly and so it would have escaped the possible contamination of the State Department, which had a higher percentage of the 'German lovers' Paris feared. Equally it was unlikely that Wilson or House would have read the over one thousand pages of documents produced, a suspicion which was well founded as Wilson was woefully unprepared when he did arrive for the Peace Conference. ${ }^{29}$

\footnotetext{
${ }^{26}$ Commission Bourgeois, meetings of 15 December 1918, and document of June 1918, 'L'Union des Alliés', 8 pp.

27 But see also the recent article by Guillaume Devin, 'David Mitrany (1888-1975): Que reste-t-il du fonctionnalisme international?', Critique Internationale (forthcoming 2008).

28 See Williams, Failed Imagination, ch. 2.

29 Report of 24 October 1918, MAE, Série A (Paix), vol. 22', microfilm.
} 
A deeper analysis was necessary. The French Diplomat so charged, Louis Aubert (André Tardieu's secretary in Washington), ${ }^{30}$ was in any case convinced that the main American desire was to 'be careful what the [American's] Allies suggest' and to keep their main immigrant populations happy and that this was the main drift of Wilson's demands for 'self-determination' - 'the influence of the Slavs of America will be felt at the expense of more democratic solutions' was one such comment. He did not think the French should make too much of their obvious claims on Alsace Lorraine as that might be seen as trying to score unnecessary points. But he did believe the Americans would accept that France had suffered greatly and therefore should be given large indemnities in recompense. He also believed that the United States would accept the need for a very strong Rhine frontier, giving them time if attacked for 'the democracies to come to France's aid'. It is worth noting that if they had secured it the Maginot Line would not have been necessary. His main finding was the France was tied to the Anglo-Saxons because the 'Thalassocraties, England and the United States' need France because they fight their land battles there and the Rhine is a perfect barrier to tanks.

As to the British, Aubert's main analysis was based almost entirely on articles by Louis Beer, an (American) Ivy League Professor in the journal Round Table. Beer was a key contact, and author of a large number of articles, (though never a member of the Round Table 'Moot') in the United States. ${ }^{31}$ As well as being a prominent member of the Inquiry, and thus a key physical link between the Transatlantic 'Thalassocracies', Beer's view was that the Americans in future must be tied into the security interests that had up till that point been solely European, an 'internationalization' of United States foreign policy. Armenia would be a perfect place for The United States to start this process, as would a 'Zionist Palestine', given their large populations of these people (and Armenia was indeed to be proposed to Wilson at the Conference). The main British interest was to get the United States to inject its capital into the Middle East to enable railways to be built - America was a nation of 'financiers and engineers' and had experience of remodelling areas 'on the scale of a continent'. Even more interestingly thought Aubert, the United States was most committed 'in the spirit of a "social worker" ' [sic in the original] to Russia and had already allocated $\$ 500 \mathrm{~m}$ through its War Trade Board.

The only doubt that Aubert expressed was about 'which America?' - that of [Theodore] Roosevelt, who would accept a strong British fleet and French army - 'In short would it be an Imperial Companion on offer' or would it be a 'provincial' America? Did Wilson represent 'les gens du village' - and if so it would be pointless to say to them 'remember [what we have gone though] ... What's the point of repeating to a people who has nothing to forget, since it has suffered very little indeed.' The problem was that the Americans had not learned to hate: '[t]he American people does not know of hate. They cut themselves off from that which is painful and horrible [odieux], like "Christian Scientists' [sic] they cut themselves off from illness, by an effort of willpower'. What Americans wanted to hear was that the French would soon forget their hatred of the Germans, 'because the American people is profoundly pacifist, has its own idealism, its belief in the basic decency of human

\footnotetext{
${ }^{30}$ My thanks to an anonymous RIS reviewer who informed me that Aubert later taught history at the Sorbonne and remained close to policymakers for the rest of his long career.

31 My thanks to Alex May for this detail.
} 
nature'. Mostly they share the 'social worker spirit' of the President, 'looking ahead' not back. So the way to appeal to them is to 'get back to business' and to their sense of fair play. But more likely it would be a case of them being unsentimental and the danger was that they would say 'America first, humanity and the international second'. ${ }^{32}$

That the French were to be disappointed in the 'Anglo-Saxon' peace as the war's first result is clear. But the above section serves to illustrate that French ideas on a possible alternative future for international relations than that which was in the end delivered by the 'Anglo-Saxons' had much more to recommend it than was seen at the time. A truly beefed up version of the Société des Nations might have contained the grave menaces that the world faced after 1919 much better than the ad-hocery that arguably prevailed.

\section{Subsequent French thinking about the future of IR, 1919-1923}

The French grew much more towards their erstwhile Allies after the Paris Peace Conference and especially after the signature of the Treaty of Versailles. A well-organised opposition to the Treaty soon developed in the United States Senate led by Republican Senators Borah, Knox and Lodge (who chaired the powerful Senate Foreign Relations Committee after the mid-term Senate elections in 1919) and early American promises of a Treaty to ensure French security came to nothing. Right after the signature of the Treaty, the temporary secretary at the French Embassy in Washington, de Chambrun, an acute observer of the United States, could see danger signals. While there might be sympathy to France there was little towards the League of Nations in the Republican Party on which the Commission Bourgeois had put such emphasis. Knox had referred to collaborating with the League as 'national suicide'. Nonetheless Chambrun felt American membership of the League was 'inevitable ... It is from now on [désormais] impossible to go back to the old theories of General Washington on entangling alliances' even if a wide variety of liberal Democrat opinion were attacking the 'Punic Peace', putting the Treaty in a vice from both ends of American opinion. ${ }^{33}$

It got worse. Even a progressive Republican from California, Senator Johnson, denounced the Treaty in June 1919 in terms which must have sent shudders through the Quai d'Orsay - 'This is not League to promote peace, but to protect power ... This League means that American boys will police the world; that all the tottering nations of the earth shall be upheld by our blood and our bone ... It means the halting and betrayal of New World liberalism, the triumph of cynical old World diplomacy, the humiliation and end of American idealism ...' De Chambrun even reported the 'applause on the floor and in the galleries' for this denunciation of a 'tottering' France, for such was how the Quai d'Orsay read this speech and many that followed. ${ }^{34}$ Neither could they count on Wilson any more, who had assured the French in Paris that from now on the United States would be a key player in world

\footnotetext{
32 Louis Aubert, Memorandum on the Inquiry, 11 December 1918, MAE (Paix), vol. 220, microfilm.

33 Chambrun to Pichon, 18 May 1919, MAE, Série B, Etats-Unis, 1918-1929, Box 38.

34 Chambrun to Pichon 2 June 1919, loc. cit.
} 
affairs, as he was ill and 'hors de combat' in a wheelchair. ${ }^{35}$ De Chambrun's colleague in Washington, Ambassador Jusserand, then had to watch as the '14 Reserve' to the Treaty in the Senate replaced Wilson's '14 Points' of January 1918 and Wilson rejected every one of them. Finally the battle of wills between the 'intransigeance du malade de la White House' was outflanked by the Senators in spite of heavy support from Versailles delegate and future President Herbert Hoover and former President Taft. The President would speak to no one, and in the end Jusserand was reduced to using an Irish priest, Tumulty ('bien disposé pour nous' as a co-religionist) as a go-between, to no avail. In the end Jusserand faced down Lodge and told him that: 'Here we have the Yorktown Alliance reversed ... Here we also have, and this is far more serious, the exclusive unity [...] of the three great liberal states compromised ... [S]o the United States loses its place in the world and the world, annoyed with them [mécontent d'eux] will forget the services they have provided. It is no small matter to lose the good will of which they were assured.' Jusserand noted that his tirade had its impact [fait effet] on Lodge, but it is clear that he reflected a widespread bitterness in France that took decades to dissipate. ${ }^{36}$

\section{Of reparations, debts and moral liability}

In the immediate postwar period all historians of the period are agreed that the main issues facing the former Allies were the same - Security and the Reparations and War Debt issues. There have been a great number of books and articles written about these and it would not be useful here to revisit those debates. But what can be done is to look at the style in which the Americans, British and the French debated them. The British debate within Government circles was essentially one of growing exasperation with the French over what was seen as their intransigence. Apart from having, in its own eyes, heroically come to the help of Belgium and France, Great Britain had acted as a clearing house during the war for capital essentially lent by the banks in the United States and passed on to France and Russia. There was a tangled web of such debts but the main discussion was on the possible separation of the debts and reparation issues and on the ability of countries to pay their debt or reparations. The Germans pleaded poverty, as did the French; the British were seen as able to pay by the United States, which in turn refused to link the issues. Many commentators see the American refusal to see what seemed an evident link in Berlin, Paris and London as either wilful ignorance or a refusal to assume leadership after the war. In defence of this position is the fact that after 1945 that is precisely what the United States did. In counter-argument writers like Shuker assert that the United States was far more generous to its creditors after 1918 than it has been given credit for. ${ }^{37}$ The debate still rumbles on ...

The French position was one that showed their frustration with its erstwhile Allies, and has to be read in the light of the rejection of the Treaty by the United States Senate. In a lengthy memorandum of October 1921 the Minister of Finance, Ferdinand Klotz, held the view that 'the French Government is entitled to claim in

\footnotetext{
35 Jusserand to MAE 13 November 1919, loc. cit.

36 Jusserand to MAE, 30 November and 8 December 1919.

37 See, for example, Shuker, The End of French Predominance, 'Introduction'.
} 
all fairness that our country owes nothing, under any form or title, to any Allied Government. ... To pay these debts would be in effect to aggravate our already shocking inequality of payment during the war.' The logic was that France had not been the sole beneficiary of the war, but had shouldered a far greater burden for it in terms of direct losses. Whereas Britain had entered to protect its economic interests which a German victory would have destroyed, the United States had entered to uphold its traditions not only of support for independence movements and freedom but to defend its own freedom and honour. So for Klotz the deal had been that while the British and Americans had partially contributed to the war financially the French had made their entire contribution on the battlefield, with death rates in France of 3.5 per cent of the population as opposed to 1.25 per cent for Britain and only 0.10 per cent for the United States. ${ }^{38}$

This assertion of its Allies' moral debt to France simply enraged the British and perplexed the Americans. The Congress set up a 'World War Foreign Debt Commission' in early 1922 in order to make sure that debt promises were respected and that the State Department did not go too soft on its erstwhile Allies' claims of financial hardship. In June 1922 Poincaré gave his representative to the Commission, Jean Parmentier, who was to be the main French negotiator on war debts until the Dawes Plan of 1924, instructions not to deny that France owed the United States money but that their payment depended on a global settlement of the debt issue. To this he added that in essence France could only pay the Americans if the Germans paid Reparations to France, which Germany was slow to do. ${ }^{39}$

There were certainly many accusations from London of French bad faith. This was not helped when the French demanded (and got) payment from Britain of $£ 25 \mathrm{~m}$ in 1919 for the use of French railways during the war to transport British troops to the Front. ${ }^{40}$ There were strong and probably justifiable feelings in London that the French did not want a solution to the financial issues as they wanted to use the debt question to tie the Anglo-Saxons into their own security concerns and to use Reparations as a club with which to beat the Germans. As Sir John Bradbury, British Official Representative on the Reparations Commission, put it, 'I am clear in my own mind that much better progress would have been made if our French friends had been content to treat the Germans as if they were really anxious, as they profess to be, to carry out the Treaty, in a reasonable and business like fashion, and had not perpetually exasperated them by a succession of demands of doubtful validity, accompanied by perpetual complaints of "mauvaise volonté" and breach of faith ... I do not think that the criticisms of the French Government of the Germans need to be taken too seriously ... I am disposed to turn around ... and bite the French.'41 As British Chancellor of the Exchequer Austen Chamberlain put it later in 1920: 'The French are very difficult to deal with for they have an incorrigible habit of going back on their agreements.' 42 These feelings get more bitter as 1920 wore on. Bradbury

38 Minister of Finance to Poincaré (at that time both Foreign Minister and President du Conseil), 22 October 1921, Seydoux Papers, 'Etats-Unis, 1921-1928', MAE PA-AP vol. 261.

39 Poincaré to Parmentier, 'Instructions', 28 June 1922, Seydoux Papers, vol. 261.

40 Franco-British Agreement of 12 March 1919, Seydoux Papers, 'Dettes Interalliées, Grande Bretagne', MAE PA-AP, vol. 261.

41 Bradbury to H. Fass (Treasury), 11 June 1920, National Archives, London, T194/5.

42 Chamberlain to Sir Hugh Levick (Bradbury's Second in Command on the Reparations Commission) 20 August 1920, T194/6. For more on this theme see my 'Sir John Bradbury and the Reparations Commission, 1920-1925’, Diplomacy and Statecraft, 13:3 (September 2002), pp. 81-102. 
himself, a technocrat and a brilliant financial expert but not one prone to understanding French 'emotional' outbursts, may have been part of the problem but it is difficult to see any other former British Treasury official behaving differently. For any of them the interests of the City and those of Britain were identical, for the French such attitudes were crass and unfeeling.

This division of perception served to further deepen the rifts that existed between the Anglo-Saxon Allies and France. They were further deepened when France invaded the Rhineland in 1923 in an effort to force the Germans to pay reparations. For London, France seemed to be set on destabilising Europe and in particular enflaming Germany. This was reinforced when a British proposal in August 1922 to cancel France's debt to Britain in return for France cancelling its reparations debt from Germany (the 'Balfour Plan') in favour of a securitised debt was rejected by France. Again the French alleged (in private) that this was all proposed by Britain in favour of the City, thus confirming the total lack of trust that now existed across the Channel. ${ }^{43}$ Although the United States and Britain had differing views about debt repayment they agreed that France was playing a dangerous game of brinkmanship. This led them more and more down a road to a technical analysis of foreign policy that is well reflected in the pages of London and Washington Think Tanks over the next ten years. It has to be said that they were very probably being unfair about French intentions and actions. From the French perspective, the Germans were trying to force their own agenda by simply refusing to pay reparations thus avoiding their central responsibility for the war as established clearly in the Treaty of Versailles. ${ }^{44}$

And underlying this there is much evidence that the French Government and wider public opinion believed that the British and Americans cared more about financial probity than about French grief over its losses during the war and its subsequent hard times as well as its real security dilemma. They often based this on the view that the British negotiation over the Reparations and debt issues seemed to owe more to pleasing the City than remembering common sacrifice. ${ }^{45}$ The French diplomatic correspondence between London and Paris at this period sees a curious juxtaposition of visits by military envoys and the dedication of war memorials, which evoked war time harmony, and bitter exchanges over the financial and wider security issues. The British and American position was to try and separate out the debt and reparation issues and see them as technical problems that just needed technical solutions in the hope that this would make for a safer, because more prosperous, Europe.

It might further be said that the reparations and debt issue shows a growing hostility within France to the idea of economic and technical solutions in general to the problems of peace and war. To see these issues, as the French did, as a way of

43 Balfour to French Government, 1 August 1922, and internal French memorandum, 21 August 1923, Seydoux Papers, loc. cit. The originator of this plan was in fact Sir John Bradbury. See Williams, 'Sir John Bradbury and the Reparations Commission'.

44 This partly explains the negativity towards Britain expressed subsequently by historians like Schuker, and many French historians such as Georges-Henri Soutou. London saw the French invasion of the Ruhr in entirely negative terms, but the French saw themselves as not giving in to German blackmail to revise the Treaty in their (Germany's) favour.

45 See, for example, Memorandum by Jacques Seydoux (Director 'Relations Commerciales' of the Quai d'Orsay) of 14 July 1922, discussing the views of the Bank of England and the City: Seydoux Papers, 'Dettes Interalliées, Grande Bretagne', MAE PA-AP, vol. 261. 
keeping Germany down and under control (another article would be required to show this detail) ${ }^{46}$ was in stark contrast to the view in London and Washington that it was part of the aftermath of the war that needed to be sorted out as quickly as possible by bankers and Governments. The French wanted their industries to dominate Germany in the Rhineland and to stop Germany developing trade links, whereas the British in particular under Lloyd George believed in a policy of 'Civilisation through Trade'. In the context of Britain, the United States and the Soviet Union this is even more striking in the 1920s. As Britain and the United States developed trade arrangements and saw a boom in exports and a relative playing down of the Soviet debt, the French became mired in endless and ultimately fruitless arguments with the Soviet Union. ${ }^{47}$ It might even be said that the 1920 s saw France dive ever more uncomfortably into corporatist non-solutions while the Americans and British tried to think more creatively and put their faith in capitalism to sort things out with their erstwhile enemies. Again, this emphasis on technical solutionseeking tended to encourage the growth of Think Tanks in Washington and London and damaged their cause in Paris.

\section{Conclusion}

In my recent Liberalism and War I stuck my neck out and suggested that:

If the nineteenth century was characterized by a meeting of the social elites, 'the aristocracies' of Europe and beyond, that of the twentieth has increasingly been defined by the meeting of elites of a different kind, ones more wedded to meritocratic advancement through the accumulation of capital and influence over democratic polities. So if, in the words of Walter Bagehot, 'nations touch at their summits', 48 the vector for that 'touching' has undergone significant changes in the last 100 years. ${ }^{49}$

The First World War was the major vector for that transition and it tended to bring the Anglo-Saxons together far more than had been the case before. After the setting up of the Anglo-Saxon Think Tanks the relationship between the main thinkers within them (and often by extension the US and British Governments and public opinions) and France went from bad to worse. One of the key vehicles for this, as we have seen, was the issue of war reparations which were the subject of much hard wrangling in 1919-1925 and practically destroyed Anglo-French friendship at official level.

The French political and administrative elite who were later to be denounced as the Fossoyeurs (gravediggers), to slightly misuse Pertinax's term of 1944 (he was mainly referring to Pétain and other political collaborators), were experiencing their last flourish before they descended into chaos to be re-born in the period of the École Nationale d'Administration in the 1940s and 1950s. But a reading of the Quai d'Orsay diplomatic correspondence of the early 1920 s is as every bit as much of a delight as

46 But, for example, see many documents in the Seydoux Papers 'Allemagne - Reparations, 1920-1925', MAE PA-PP, vol. 261.

47 For detail on this, see my Trading With the Bolsheviks: The Politics of East-West Trade, 1920-1939 (Manchester University Press, 1992).

48 W. Bagehot, The English Constitution, 1867, Chapter on the 'House of Lords', quoted in the Oxford Concise Dictionary of Quotations (Oxford University Press, 1997), p. 26.

49 Williams, Liberalism and War, p. 41. 
reading that of the Foreign Office or the State Department of the same period. ${ }^{50}$ If the French foreign policy elites made a foundational mistake after the First World War it was that they chose a system of making political decisions about the future of France and Europe based on a much more backward-looking and emotional appeal than did the Anglo-Saxons. Their obsession with the needs of reparation and indemnity completely misread the desires of the foreign policy elites in the United States and Britain for new thinking. By refusing to engage in that debate, or by setting up their own Think Tank at that time, it might be argued that the French wrote themselves out of the debate about the global future. France now has such bodies, though they are fewer and arguably not so influential as in Washington or London but in the meantime they were not able to stop the establishment of what was essentially an Anglo-American vision of a New World Order, the basic framework of which we are still working with today.

It must not be thought that the subsequent relationship between the 'AngloSaxons' and the French was all bad or that that among the Anglo-Saxons was all good, ${ }^{51}$ but it has to be said that one of the reasons why the Anglo-American Special Relationship had continued to largely flourish ${ }^{52}$ has been because of the ties of which Think Tanks are both symptom and cause. This has had other consequences. International Relations (IR) as a discipline has tended to freeze out French scholarship, with only Raymond Aron generally given membership of the top table of past Second Word War theorists, as the Anglo-Saxons have tended to freeze out French policy options for the reordering of the global system. When Edith Piaf went to America she was initially misunderstood - only when she started to sing in English was she really appreciated. Chris Brown has spoken cogently of the 'Anglo-Saxon leanings' of IR and these 'leanings' will always crop up sooner or later at international conferences where the French dare to raise their heads above the parapet, much to the sadness of at least this Anglo-Saxon.

But much more seriously, the dominance of Anglo-Saxon Think Tanks has tended to reinforce the belief that the French are somehow wrong-headed about any of their policy choices. So they are currently in the dock over Rwanda and Iraq. It is forgotten that they have been very self-critical over the former and (probably) right over the latter, but they are still excoriated as 'cheese-eating surrender monkeys'. What this article has hoped to shed some light on is the origins of that feeling. France's experience of two wars against Germany gave it a strong belief in state-to-state diplomacy and security based on ties of 'justice' and 'honour', but without idealist illusions about the existence of an international 'community' as the basis of sound international relations. They have also consistently wanted to bind themselves and others to strong institutional structures and to be able to defend their

${ }^{50}$ I can claim some affection for these as I spent a month researching in the Quai d'Orsay Archives for a bigger project than even this one, with particular attention being given to the Correspondance Politique et Commerciale: États Unis, 1918-1929, especially Box 38, May 1919-February 1920; and: Europe, 1918-1929, Grande Bretagne, June 1921-August 1922, especially Boxes 47-49. My thanks to Bertrand Badie and Guillaume Devin in particular and Sciences Po, Paris, in general, for having me there as a professeur invité in Spring 2006.

51 See my 'Before the Special Relationship: The Council on Foreign Relations, The Carnegie Foundation and the Rumour of an Anglo-American War', Journal of Transatlantic Studies, 1:2 (2003), pp. 233-51.

52 Though not always of course; see John Dumbrell, A Special Relationship: Anglo-American Relations for the Cold War to Iraq, 2nd edn. (Houndmills and New York: Palgrave Macmillan, 2006). 
national interest with a distinctly corporatist tinge in the face of what they see as Anglo-Saxon inspired 'mondialisation' - globalisation (often stigmatised in France as 'hyper-liberalisme') - or ill-considered interventions in places that are best left well alone.

In this they are arguably the natural inheritors of a nineteenth century noninterventionist and statist liberalism (even 'solidarité' as Léon Bourgeois might have put it and many French intellectuals would now term it), fighting a rearguard action against twentieth century globalising and muscled humanitarian interventionism led by the United States. Maybe we could say that the Anglo-Saxons have been wrong to dismiss French thinking about IR as 'backward' (as I have myself to some extent in my own Anglo-Saxon arrogance) but should rather see it as prescient in emphasising the necessary social and internal solidarity of all members of the international society. In the light of what is happening in Iraq, maybe their time is coming again? 